\title{
Women's Clubs in Iowa: An Introduction
}

\author{
KAREN M. MASON
}

"[WHEN] I WAS ASKED to join a woman's club . . . I'm afraid I thought of all the cartoons of club women; I wasn't sure I wanted to be one," recalled Dorothy Deemer Houghton in 1968. Wanting to become acquainted with her neighbors, she joined a club nonetheless and eventually rose through county and district offices to become president of the Iowa Federation of Women's Clubs (IFWC) in 1935 and of the national organization, the General Federation of Women's Clubs (GFWC), in $1950 .^{1}$

As Houghton's remarks indicate, club work was often ridiculed or trivialized by the press and by social critics, the significant accomplishments of women's organizations overlooked. Over the past two decades, however, women's historians have built a substantial body of literature on the club movement, from Karen Blair's pathbreaking, though flawed, 1980 monograph, The Clubwoman as Feminist; to Anne Firor Scott's monumental survey, Natural Allies: Women's Associations in American History (1991). Historians have analyzed the important function these organizations played in women's lives, the community building they accomplished, and the extent to which women shaped social welfare policies and institutions through their activism. ${ }^{2}$ The four essays gathered in this special issue of the

1. Dorothy Deemer Houghton, Reflections (Privately published, 1968), 32-39.

2. Karen Blair, The Clubwoman as Feminist: True Womanhood Redefined, 1868-1914 (New York, 1980); Anne Firor Scott, Natural Allies: Women's Associations in American History (Urbana and Chicago, 1991). Blair's monograph helped to show that women's club work was worthy of serious study. She was overly

THE ANNALS OF IOWA 56 (Winter/Spring 1997). CThe State Historical Society of Iowa, 1997. 
Annals of Iowa build on this literature, viewing organizational activity as an important avenue to civic involvement. They move the discussion forward by illuminating the interplay of national political trends with the local political climate and actors. By so doing, they offer a more textured analysis of women's efforts to define a new public role for themselves.

Christine Pawley's article about a women's study club in the period before women won the vote in 1920 traverses wellknown territory but situates a particular club and its members within the socioeconomic structure of a small Iowa town, allowing a richer understanding of how the club was able to move successfully from self-improvement to a public leadership role in the community. Two of the articles examine organizations that have been virtually ignored by historians, the Daughters of the American Revolution (DAR) and Republican women's clubs. Because the resurgence of pacifism in the 1960s and 1970s sparked a flurry of scholarly studies on the earlier international peace movement, mainstream historians have paid more attention to the Women's International League for Peace and Freedom (WILPF) than most women's organizations. But previous studies have focused on the national and international pacifist movement, largely ignoring state and local leagues. ${ }^{3}$ In addition, Kim Nielsen and Catherine Rymph's focus on the years after 1920, as newly enfranchised women attempted to define their role in the electorate, adds a welcome perspective to the study of women's clubs. Each of the essays thus fills significant gaps in the literature on women's organizations, and together they illustrate both the diversity of women's organizational

zealous, however, in ascribing a feminist consciousness to clubwomen; most, though not all, would not have characterized themselves that way. Other monographs on the club movement include Theodora Penny Martin, The Sound of Our Own Voices: Women's Study Clubs, 1860-1910 (Boston, 1987); Janice C. Steinschneider, An Improved Woman: The Wisconsin Federation of Women's Clubs, 1895-1920 (Brooklyn, NY, 1994); Genevieve G. McBride, On Wisconsin Women: Working for their Rights from Settlement to Suffrage (Madison, 1993); and a number of other state-level studies.

3. See, for example, Charles DeBenedetti, Origins of the Modern American Peace Movement, 1915-1929 (Millwood, NY, 1978); H. C. Peterson and Gilbert C. Fite, Opponents of War, 1917-1918 (Seattle, 1968); and Barbara J. Steinson, American Women's Peace Activism in World War I (New York, 1982). 
experience and the varied ways women understood their political roles.

CLUB WORK was a fact of life for many Iowa women in the last decade of the nineteenth century and the first half of the twentieth century. The number of women who belonged to organized clubs in this period is astounding. The lowa Federation of Women's Clubs organized in 1893 with thirty-five clubs as charter members and affiliated with the GFWC the same year. The number of affiliated clubs in Iowa grew rapidly, reaching 284 by 1903 and 931 by its peak in 1933. By that time, the IFWC represented more than forty thousand women. Iowa was not unusual in the degree of organization of its women, although it did earn the distinction of being the first state organization admitted to the GFWC. And Iowa's DAR competed with Ohio's for the claim to be the largest state branch of that organization in the Midwest after $1904 .^{4}$

But the federated clubs and the DAR were not the only organizations for women. In addition to the DAR, with its attention to preserving monuments of the past, Iowa women worked to secure a better future through suffrage organizations and other reform-minded groups. With the ratification of the Nineteenth Amendment granting women the vote in 1920, suffrage organizations dissolved or were transformed into new organizations, such as the League of Women Voters (LWV). New associations such as the Business and Professional Women's Clubs emerged to meet the needs of employed women. In short, the opportunities for membership were many and varied.

Women joined clubs for diverse reasons. The initial motivation was often social; for wives and mothers, clubs were a means of meeting other women and conversing about issues beyond the mundane. As Dorothy Houghton explained, "Housewives need the mature social contacts women's clubs offer. As companions small children are frequently amusing and always beloved, but

4. Hazel P. Buffum, "Iowa Federation of Women's Clubs: Historical Beginnings," Palimpsest 34 (1953), 213-15, 222; Francesca Morgan, "Regions Remote from Revolutionary Scenes': Regionalism, Nationalism, and the Iowa Daughters of the American Revolution, 1890-1930," Annals of Iowa 56 (1997), 47-48. 
they are not intellectually stimulating. Neither is an unrelieved regimen of laundry, cookery, and dishwashing. ${ }^{15}$ But as Pawley and Morgan's articles illustrate, social contact was only part of the attraction of women's clubs. The numerous activities undertaken by clubwomen - whether working to establish libraries, kindergartens, and playgrounds or lobbying for child labor legislation - gave women "a feeling of working for something worthwhile" and at the same time promoted the welfare of the community. ${ }^{6}$ Furthermore, "being active in club work is truly a form of adult education for many women, and holding an office is excellent training for leadership in other fields. The opportunities afforded by women's club work for developing poise, for learning and for leading are unparalleled in any other phase of a woman's life." The Republican Party's women's committee recognized this when it used the model of club work to attract women to party politics. Most women never gained the leadership roles they hoped for within the party, but they developed useful skills that may have served them elsewhere.

The Shakespearean Club in Osage, Iowa, began in 1881 as an informal gathering of men and women. The men had dropped out by 1890 , but the women continued to meet twice monthly to study a variety of topics. Their aim was self-education, but their activity was not confined to literary study: from the beginning, members presented papers on such political issues as the "labor problem" and the property rights of married women. They debated the propriety of women's work outside the home and the wisdom of granting women the vote. After 1900 these discussions were accompanied by action outside the meetings: club members worked for the establishment of playgrounds and libraries, participated in anti-smoking and anti-spitting campaigns, and wrote to state senators and representatives to express their support of widows' and teachers' pensions, the inspection of working conditions in factories, and woman suffrage. This activity, according to Pawley, laid claim to certain areas of the political agenda.

5. Houghton, Reflections, 37.

6. Ibid., 34.

7. Ibid., 37. 
The activities of the Shakespearean Club mirrored those of many women's clubs throughout Iowa and across the nation in the decades around the turn of the century. Beginning with the rather modest aim of self-improvement or self-education, study clubs gradually broadened their scope of study and expanded their activities out into the community. The mission of the Iowa Federation of Women's Clubs, for example, was explicitly literary at first, but within two years of the Federation's formation the organization was promoting political and social causes. As Hazel Buffum wrote in her history of the IFWC, "Long before they had the right to vote, clubwomen in Iowa were working to secure passage of laws which affected the welfare of children, the home, and the community. The legislation committee, first appointed in 1895, receives recommendations from other committees, marshals arguments, and presents them to the legislature. Where it will help, all clubs are informed and asked to study the matter and then write their opinions to senators and representatives from their own districts. ${ }^{18}$

This involvement in political activity, particularly the promotion of child welfare legislation, extended to even the most conservative organizations, such as the DAR, illustrating the degree to which diverse groups embraced the spirit of progressivism. Francesca Morgan's article presents surprising information about the little-studied DAR, overturning many of our assumptions about that organization. Morgan challenges popular conceptions of the DAR as little more than a patriotic organization interested primarily in its members' genealogical ties to the American Revolution.

Membership in the DAR provided some of the same social interaction and intellectual stimulation as did the study clubs of the General Federation. Furthermore, associating with "the pillars" of upper middle-class society in Iowa towns and cities bestowed social prestige on its members; this social aspect of club involvement should not be minimized.

The DAR especially appealed to women who were interested in history and genealogy; the historical projects they undertook gave them a feeling of contributing something to their community

8. Buffum, "Iowa Federation," 228. 
and at the same time encouraged patriotism in "regions remote from revolutionary scenes." The vitality of the DAR in Iowa in the early twentieth century was due in large part to its willingness to adapt its historical agenda to include a focus on local history.

But the Iowa DAR undertook other sorts of projects as well, including the "patriotic education" of new immigrants and, most surprising of all, lobbying for child labor laws and other social welfare legislation. The Iowa DAR's promotion of reform ended with the onset of World War I, pushed aside by war relief work and loyalty campaigns. By the 1920s, the DAR had turned its focus to Americanism and anticommunism, engaging in the nativism and red-baiting we often associate with the organization. While some members posed modest resistance to this trend, most went along with it.

In at least some places, the Red Scare of the 1920s resulted in overt conflict between clubwomen. When the Women's International League for Peace and Freedom (WILPF) attempted to organize a chapter in Sioux City in 1926, local and state DAR officials joined with the American Legion to try to stop the pacifist group. In addition, DAR and WILPF members battled for control of the local chapter of the League of Women Voters. The women who organized the Sioux City WILPF had been active in other women's organizations. They no doubt expected to be accorded respect and to wield influence as women had long done through their clubs and organizations. Instead, they were met with hostility and condescension from the local press and American Legion members, young veterans who believed they understood a good deal more about international affairs than did these middle-aged society women seeking disarmament. Generational and class differences exacerbated the ideological conflict. And while WILPF members' gender "handicapped claims to political authority," this was not simply a contest between men and women; women took both sides in the dispute. In the end, the WILPF was soundly defeated and went out of existence. ${ }^{9}$ 
Kim Nielsen's examination of the dispute between American Legion members and WILPF members in Sioux City reminds us that women did not enter easily into the electorate after winning the vote. Instead, "vigorous debate . . took place in the 1920 s about the public role and political participation of the newly enfranchised female citizen. ${ }^{\prime 10}$ Nielsen's layered analysis fulfills the promise of women's history: rather than studying women in isolation, it places them in a pivotal role in the story but looks as well at the entire context of the dispute, examining the possible motives of all of the actors. ${ }^{11}$

Nancy Cott has stressed the continuity in women's political activity before and after the passage of the Nineteenth Amendment as women continued to wield influence through voluntary organizations and the use of lobbying after $1920 .{ }^{12}$ When women moved from women's clubs into more explicitly political organizations, however, they encountered obstacles, from other women as well as men. Catherine Rymph suggests that Republican women who drew upon traditional forms of associational activity met less resistance than did others, and were able to attract women who might otherwise not have taken an active political role.

The Tama County Republican women's clubs were first organized to drum up support for Herbert Hoover in the presidential election of 1928. As Rymph notes, "the vast majority of American women were uninitiated into formal political activities - voting, campaigning, stumping" - when they received the vote in 1920 and so had to be educated as well as courted by the parties. Women leaders sought to bring women voters into politics by combining social and political activities: "Partisan clubs, by embracing the techniques, values, and traditions of existing women's clubs," could help ordinary women "experience their party as something that belonged to them, and as

10. Ibid., 80 .

11. Rebecca Conard's work has similar strengths. In Places of Quiet Beauty: Parks, Preserves, and Environmentalism (Iowa City, 1997), 26-30, 78-84, she places clubwomen squarely in the movement for state parks, along with natural scientists and other environmentalists, analyzing the role of each group and the interactions among them.

12. Nancy F. Cott, The Grounding of Modern Feminism (New Haven, 1987), 85-86. 
something with which they could identify." ${ }^{13}$ The clubs, built from existing social networks, held meetings in parks, libraries, homes, and churches; while including information about the Republican Party and about candidates, events were intended to be fun. Some were geared specifically to women, others to the whole family and community.

The Republican women's clubs did succeed in developing women into Republicans and in diminishing the association of partisan political activity with men and masculinity. Through these "women-centered political spaces" women carved out a role for themselves in the party, taking over "the grass-roots work of party politics - the social, educational, and recruitment activities that gave the party a local face. ${ }^{14}$ But they failed to move into policy-making roles and thus were not fully integrated into the party; it was a rare woman who had a role in decision making.

Mary Louise Smith, who got involved in Republican Party politics around 1948 in Eagle Grove, Iowa, noted the discrepancy between men's and women's roles in the party.

There were no men around. I was going to campaign headquarters and answering the telephones and doing mailings and going doorto-door canvassing and it was almost entirely female. That piqued my curiosity. It seemed to me that surely it was not a party of all women. I knew there were men someplace. The more you began to inquire, what you found was that they were doing the policymaking things. Many of them were down in Des Moines. . . . When I came to that realization, I suppose that sparked me to do some goal setting. If I was going to spend time doing volunteer work in the area of politics, or anything else as far as that's concerned, then I would want it to be worthwhile. I would not want to be just spinning my wheels some place, but having something to say about the organization and about the programs and about the direction that the party was going. ${ }^{15}$

13. Catherine E. Rymph, "'Keeping the Political Fires Burning': Republican Women's Clubs and Female Political Culture in Small Town Iowa, 1928-1938," Annals of Iowa 56 (1997), 105, 107.

14. Ibid., 126.

15. Louise R. Noun, More Strong-Minded Women: Iowa Feminists Tell Their Stories (Ames, 1992), 148. 
For women like Smith who were aggressive enough to demand a voice in party affairs, this grass-roots work sometimes led to a more central role in the party. Smith worked her way up through the ranks to become chairman of the Republican National Committee, serving from 1974 to 1977.

Together, the Pawley and Rymph essays illustrate both the strengths and weaknesses of the separatist model of female political activism. The women of the Shakespearean Club were able to influence community life from outside the electorate. When the club became so influential that someone suggested admitting men to membership, the club refused, knowing that men would take over the leadership roles and women would lose their voice in local affairs. They chose to maintain a separate female organization, which exists to this day. ${ }^{16}$

By contrast, the Republican women's clubs, hoping to build the same sort of loyalty to the party that women felt to their clubs, found that separatism had ambiguous results in the new political context. Thinking that these clubs would be a route to power and influence within the party, Republican women discovered instead that they were consigned to an essential but merely supporting role within the party. "The separate partisan culture that eased women into the party by serving as a bridge between women's traditional organizations and party organizations ultimately proved to be an end in itself."

The insightful analysis of the Shakespeareans, the DAR, and WILPF is enriched by the authors' research on the age, marital status, class, religion, and occupation of members. Each of these clubs comprised prominent, middle- to upper middle-class white women, who were for the most part mainstream Protestants. Most were married or widowed. Some, but not many, worked outside the home for pay. This biographical information helps to explain the context within which each organization operated. And in important ways it contributes to our understanding of Iowa history. For example, Pawley's discussion of the one Jewish member of the Shakespearean Club (and member of the only

16. Christine Pawley, "Not Wholly Self Culture': The Shakespearean Women's Club, Osage, Iowa, 1892-1920," Annals of Iowa 56 (1997), 43-44.

17. Rymph, "Keeping the Political Fires Burning," 127. 
Jewish family in Osage) illuminates the experience of a religious minority in small-town Iowa. Despite being the one Jew in an organization of Protestant women, Mrs. Katz was apparently well respected, holding leadership roles in the club and presenting papers on Judaism and on international issues of concern to Jews. Clearly, the women of the Shakespearean Club felt that similarities of class and conscience outweighed differences of religion.

Although the members of the clubs examined in these articles were well-to-do white women living in small towns and cities, the club movement was by no means confined to such women. Farm women participated in Farm Bureau women's organizations, but also established women's clubs similar to those of their town and city counterparts. Those living near Grimes, Iowa, formed the Daughters of Ceres in 1898. This club filled an important social function for farm women, but also performed charitable activities. African-American women in the mining town of Buxton, Iowa, likewise formed various organizations, ranging from social and literary clubs to lodges, church circles, and reform-oriented groups. ${ }^{18}$

Women's organizational activity has declined in the latter part of the twentieth century for a number of reasons, not least of which is the increase in the number of women working outside the home. Certainly women's increasing integration into public life makes women's clubs less essential than they were at one time. But while they may not all be as vital as they were three-quarters of a century ago, literary clubs, the DAR, and the WILPF continue to exist. And the tradition of separatist organizations has re-emerged with the growth of business and professional women's associations formed for the purpose of networking and political organizations designed to raise funds for women candidates.

The following essays help us rethink many of our assumptions about women's clubs, whether they be stereotypes of lit-

18. Julie McDonald, Ruth Buxton Sayre: First Lady of the Farm (Ames, 1980); Daughters of Ceres Records, Iowa Women's Archives, University of lowa Libraries, Iowa City; Dorothy Schwieder, Joseph Hraba, and Elmer Schwieder, Buxton: Work and Racial Equality in a Coal Mining Community (Ames, 1987), 156-58. 
erary clubs as means for leisured women to fill empty hours or the belief that reform-minded women shared a common ideology. One of the most important conclusions to be drawn from these articles is that women were not unified in their beliefs. The ideological contrast between the DAR and WILPF in the 1920s, vividly highlighted in the articles by Morgan and Nielsen, demonstrates "the historical inaccuracy of referring to women as a cohesive, interest-sharing political group. ${ }^{19}$

The essays in this issue describe the significant activities and accomplishments of women's organizations in Iowa, which were similar to those of women's clubs across the country: building libraries, establishing kindergartens, lobbying for child welfare legislation, preserving historic sites. They also provide insight into questions regarding women's political behavior that have occupied women's historians for some time. Even more importantly, they expand our knowledge of Iowa history, contributing to our understanding of how national political and ideological struggles played out on the state and local level. At the same time, they illustrate how valuable state and local studies are for understanding broader issues, such as women's emerging political role or the Red Scare of the 1920s.

Nonetheless, these articles barely scratch the surface of women's organizational activity in Iowa. The numerous collections of organizational records held by the major repositories in Iowa, along with the many records in local historical societies, libraries, and private hands, contain a wealth of information for historians. ${ }^{20}$ Too often women's club records have been considered useful only for the study of women's history. Such a limited perspective impoverishes our history by ignoring significant sources of information about local, state, and national developments. The imaginative use of sources by the authors in this issue suggests how the use of women's club records can enrich our understanding not only of the history of women, but of society writ large.

19. Nielsen, "Dangerous Iowa Women," 98.

20. See the listing following the four feature articles in this issue. 
Copyright of Annals of Iowa is the property of State of Iowa, by \& through the State Historical Society of Iowa and its content may not be copied or emailed to multiple sites or posted to a listserv without the copyright holder's express written permission. However, users may print, download, or email articles for individual use. 